How to cite this article:

Abu Bakar J., Mohamad Z. Z., S. A. Sharmeela-Banu, Ganapathy, T. (2020), Empirical evidence of obstacles of women entrepreneurship's growth in Malaysia. Journal of Business Management and Accounting, 10(2), 67-84.

\title{
Empirical Evidence of Obstacles of Women Entrepreneurship's Growth in Malaysia
}

\author{
Juliana Abu Bakar*, Zam Zuriyati Mohamad, Sharmeela-Banu, S. A., \\ Thavamalar Ganapathy \\ Faculty of Business and Finance, Universiti Tunku Abdul Rahman, \\ Kampar, Perak, Malaysia
}

Received: 11/3/2020 Revised:8/7/2020 Accepted: 12/7/2020 Published: 15/11/2020

\begin{abstract}
Women's equality and empowerment are one of the 17 Sustainable Development Goals that was initiated to eliminate gender discrimination. This goal can be achieved through establishing women entrepreneurship by employing critical failure factor analysis. Thus, this study was aimed to explore the obstacles faced by women entrepreneurs; consisting of restricted training and education, legal constraints, limited access to financial resources, and family-related interface. Besides, this study was intended to examine how these obstacles affected women entrepreneurs' growth. Data related to 109 women entrepreneurs in Malaysia were collected. The Relative Importance Index (RII) was used to rank these obstacles. Subsequently, partial least square structural equation model analysis was performed on the data. The findings revealed that restricted training and education, limited access to financial resources, and familyrelated interface have an adverse effect on women entrepreneurs' growth. Therefore, theoretically this study offered a new women entrepreneurs' model by linking the obstacles and growth within a single study.
\end{abstract}

Keywords: Women Entrepreneurship, Training and Education, Financial Resources, Family-Related Interfaces, Critical Failure Factor, Relative Importance Index

* Corresponding Author: Tel: +6054688888 (Ext: 4309), Fax: +6054661313

E-mail: juliana@utar.edu.my 


\subsection{Introduction}

Entrepreneurship is an important key for a nation's economic growth through the establishment of a new business as it provides more job opportunities, toughens the competition in the market which leads to higher productivity. According to the GEM 2016/2017 Women's Entrepreneurship Report, 163 million women worldwide started their businesses with Total Entrepreneurial Activity (TEA) in 2014. Their involvement in businesses increased by $10 \%$ and continuously showed a positive trend in 2018 where it was raised by $7 \%$, while the gender gap between women and men was decreased by an average of $6 \%$.

The largest involvement of women in entrepreneurship is the age group of between 25-34 and 35-44 years-old (Minniti, 2010). According to Women Entrepreneurs Law and Legal Definition, "women entrepreneur" is referred to as the involvement of women who participate in organising and managing enterprises. It is essential to boost participation of women to enter male-dominated sectors, because if women are able to break the male-dominated sectors it would change the mindset of financial institutions to provide new opportunities for women to absorb, develop, and grow more entrepreneurial businesses. Moreover, the participation of women in business activities, especially in developing countries, can help their society to reduce poverty and as well as improve their country's economic condition. Due to being equipped with the necessary information, a new brand of women entrepreneurs with new directions have appeared nowadays, and who have important knowledge of business orientation for them to be successful in their entrepreneurial activities. These directions include risk-taking behaviour, creativeness and innovativeness, multi-tasking, and ability to manage manpower challenges that arise. Recently, the number of women involved in entrepreneurial responsibilities had increased, especially the trend of women involvement in healthy business activities. However, despite this rapid growth, there is a substantial number of women who are still involved in business at the micro-level, and they still do not have the confidence in promoting their business activities globally.

The Sustainable Development Goals (SDGs), also known as the Global Goals by United Nations General Assembly in 2017, United Nations Development Programme (UNDP) worldwide under UNDP's Strategic Plan (2018-2021) is calling for action to reduce poverty, defend the earth, and ensure that all people enjoy peace and prosperity by 2030. Furthermore, SDGs also aim to achieve gender equality and empowerment among all women to be a part of the 17 strategic plans listed in goal lists. Applying new legal outlines regarding gender equality at work and the extinction of destructive practices on women are the crucial tasks to stop gender-based discrimination practised in many countries worldwide.

The Global Entrepreneurship Monitor Report 2015/2016 recorded that during 2016 and 2017 compared to men, it seems that women are more expected to start businesses 
in all regions, except in North America. Eliminating the gender gap in terms of their business activity involvement still becomes a priority focal point for policymakers in all economies. In Malaysia, the participation of women in business activities is about the same as men, especially in small and medium enterprises (SMEs). Many of these Malaysian women entrepreneurs are facing difficulties and different challenges which includes lack of support from others, especially from their own family, lack of confidence in starting a business, and high barriers including biasness from their male counterparts (The Global Entrepreneurship Monitor Report 2015/2016).

However, the government is encouraging women to participate in business activities by providing many sources including entrepreneurial grants, bases of funds, and also organising numerous programmes to motivate and give guidelines for new female selfstarters in Malaysia. In addition, Malaysia Budget 2019 also brought good news for entrepreneurs. The government highlighted the focus on institutional restructuring, society's welfare, and advancement of business culture to achieve Malaysia's "Economic Tiger" status. SMEs represent $98.5 \%$ of businesses activities in Malaysia, and have received the main enhancement from the 2019 Budget, including initiatives on tax exemption for specific business-to-business service tax. A credit system is given for small producers who are involved in international business activities, especially those that import raw materials and intermediary goods from other countries. The focus point listed in the 2019 Budget seems to be very realistic as a platform to encourage and empower more Bumiputera and local entrepreneurs to start up or enhance their businesses at a higher level. Meanwhile, the Ministry of Entrepreneur Development (MED) expects to see more opportunities for business activities, including SMEs in the service sectors, as a result on the initiative taken by the government to impose taxes on imported services.

Despite all the positive news, there is still room for improvement to help women entrepreneurs in business start-up. The government is helping by providing more support mechanisms and better strategies, especially in stipulating source of funds for women. Some of them include Women Entrepreneur Financing Programme, SME Bank, Women of Will, Temanita Financing Scheme, Tekun Nasional, Amanah Ikhtiar Malaysia (AIM), National Entrepreneurship Institute (INSKEN), Global Accelerator Programme, MAGIC, Cradle Investment Programme, Cradle Fund Sdn Bhd, and many others (UNDP Strategic Plan, 2018). Most entrepreneurs are aware of all these facilities provide to them. The current policy inclination is to establish a comprehensive microfinance institutional framework to promote the development of a sustainable microfinance industry in Malaysia, providing microenterprises an important avenue to obtain financing from the formal financial system. As at the end of December 2007, there were 22,788 microfinance accounts with total financing outstanding of RM224.7 million, up from 2,000 accounts with total outstanding of RM25.6 million just a year before (UNDP, 2008). 
The trio formation of the Ministry of Women, Family, and Community Development and also National Policy on Women are also important to ensure the success of women as entrepreneurs. In trying to reach out to women in the rural areas, government support is given via non-governmental organisations in terms of training programmes, financial and technical assistance, information resources, development and consultancy, workshops on motivation, leadership, and so on (Ariff \& Abubakar, 2003; Xavier, Ahmad, Nor $\&$ Yusof, 2012). In short, the Malaysian government has been continuously investing and cultivating an enterprising culture among Malaysian women. National Association of Women Entrepreneurs of Malaysia (NAWEM) was designed by the government and aimed to create a guideline as a platform in supporting women to empower and develop their business, which included providing leadership, inspiration, and role models (Kuppusamy, Ganesan, \& Rosada, 2010). Various other women entrepreneur association such as FEM and USHANITA together with industry associations play the role by providing a stage for businesswomen to create, expand their network, and exchange experiences and information (Xavier et al., 2012). In conjunction with the women entrepreneur phenomenon, this study intended to achieve two objectives; firstly, to explore obstacles faced by women entrepreneurs using critical failure factor and secondly, to examine how these obstacles affected women entrepreneurs' growth.

\subsection{Literature Review}

This section focuses on the literature review of women entrepreneurship, mainly issues and challenges faced by women entrepreneurs relating to training and education, legal constraints, limited access to financial resources, and family-related interface.

\subsection{Training and Education}

Entrepreneurship education and training are important entrepreneurial activities as it is a good platform to promote business activities such as initiation, creation, and sale of unique products to meet consumer needs.

Entrepreneurship education, according to Baba (2013) is the processes of gaining knowledge, attitudes, and skills of entrepreneurship. It can help to increase entrepreneurs' ability to search for good investments with the best returning opportunities. The lack of proper education becomes a major challenge for businesswomen, especially in developing countries. Thus, women are not able to understand and identify the procedures on how to start a small-scale business. Uneducated women are less expected to form their own business and lower levels of education may become one of the reasons for a lower survival rate for women in business activities (GMI, 2014). The implication of the current study by Obilo (2014) found that education may influence the performance of women's involvement in business activities and with a higher level of education, they can perform better. 
Entrepreneurship training is a programme designed to influence skills and attitude to assist entrepreneurs to start a new business or enlarge an existing one (Kithae, Maganjo, \& Kavinda, 2013). It can increase the number of entrepreneurs as well as employment opportunities that will facilitate economic growth and development of a country (Maryam, Mbasua, \& Fatima, 2017). Norman (2013) revealed that training is a coaching process for skilled achievement. It is aimed to help women overcome obstacles they face in managing their businesses. It can also improve both firm performance and overall levels of well-being (Olena, 2014). Based on the above studies, the following hypothesis was developed:

Hypothesis 1: There is a significant effect of training and education to reduce obstacles in women's entrepreneurship growth.

\subsection{Legal Constraint}

Women entrepreneurs have to face serious complications due to legal barriers created by the government. These barriers include business regulations, taxation, and some other legal procedures. Though these barriers are problems faced by both men and women entrepreneurs, women are facing more difficulties with them when compared to men, as women are not educated enough to meet the challenges created by these legal barriers (Vossenberg, 2013). Due to bureaucracy, inefficiency of large-scale production, lack of initiative, and ineffective decision making, all of these hinder the development of women entrepreneurship (Jahed, Kulsum, \& Akther, 2011). Haper (2004) identified that authorities are not concerned to promote business activities especially SMEs, and they fail to observe the implications of various programmes and policies in informal sectors.

Different regulations, diversity of laws, and government policies are the main hurdles for the entrepreneurs and development of business. Higher rate of conspiracies and bureaucracy, social security's contribution, taxes on the company, personal income taxes, fiscal and monetary policies, and labour law all represent governmental interference with the most negative effects on businesses (OECD, 2019). Therefore, legal and regulatory activities have been stated as one of the important factors in influencing women entrepreneurs to start enterprises and running their businesses (Obilo, 2014). Women entrepreneurs may decrease legal impacts by applying a proactive strategy and preliminary study (Md Isa, Jaganathan, Ahmdon, Afiq, \& Mohamad Ibrahim, 2018).

In many developing countries, women do not enjoy protection in entrepreneurial activities to upgrade, due to the lack of legal guidelines and clear property rights (GMI, 2014). In Bangladesh, women are mostly engaged with small and mediums sized businesses as they do not have sufficient power to influence in the policymaking to make it favourable for them (Jahed et al., 2011). Therefore, government policy is not always 
advantageous for protecting the real interests of women entrepreneurs, particularly in areas that matter for promoting their involvement in the economic development process in their country (Meherun, 2014). Based on the above studies, the following hypothesis was developed:

Hypothesis 2: There is a significant effect of legal constraints to reduce obstacles on women's entrepreneurship growth.

\subsection{Family-Related Interface}

Most women are burdened with work at home and business activities at the same time. They believe that whatever their position in their business, they will have to still focus on their responsibilities at home. They need to do house chores and take care of their children, which causes difficulties in maintaining house chores and business activities at the same time (Gill \& Ganesh, 2007). Based on the study done by Obilo (2014), he found that household commitments become one major concern that may affect the performance of women entrepreneurs in Kisauni sub-county. Additionally, marital status also influences women's participation in entrepreneurship activities, as some husbands do not allow their wives to be involved in businesses, while some are very supportive and even help with financial aid. This study showed that variables such as having children and taking responsibility as housewives while doing businesses are the main reasons that prevent women to involve themselves in entrepreneurship (Obilo, 2014). Marital status of a woman is important because a married woman has more responsibilities at home as compared to an unmarried woman. Furthermore, research showed that women are more successful when they do not attempt to integrate family with their business (Akehurst, Simarro, \& MasロTur, 2012).

Meanwhile, Carter and Shaw (2006) identified that some variables such as having children have no statistical relation with business performance. However, the responsibilities as a housewife still becomes a main constraint for some women who wish to start their own business. This result is in line with the study done by Obilo (2014), who stated that the unnecessary demand of women as wives, mothers, and managers of the house makes it difficult for women to run and manage the business at the same time.

Furthermore, women's responsibilities and commitments restrict their ability to move forward in business. Their obligation toward the family, especially their children, limits their mobility to generate income. The inability to balance their time, energy, and resources between family and business will cause business failure (Loveline, Uchenna, \& Karubi, 2014). Therefore, family support is found to be one of the important factors for women who want to create their own businesses. Thus, it has been found that 
female entrepreneurs need to have support from their family members and society as a whole (Akehurst et al., 2012). Based on the above studies, the following hypothesis was developed:

Hypothesis 3: There is a significant effect of family-related interface to reduce obstacles on women's entrepreneurship growth.

\subsection{Limited Access to Financial Resources}

Generally, women face problems in collecting funds for their business and sometimes they also experience discrimination from financial institutions. Lack of capital in the initial stages can have negative long-term effects (Akehurst et al., 2012). Access to financing and capital is an important factor for the survival of businesses, since in situations of insufficient financial support will cause entrepreneurs to be unable to produce new products and services, or to create new jobs (Akehurst et al., 2012). Besides due to lack of proper business education, many women do not know about formal procedures to obtain financial support from banks to initiate their business. Besides, complex procedures for obtaining bank loans, lack of tax regulations, and lack of necessary papers like bank accounts and guarantees for bank loans hinder the access by women to finance their businesses (Rabbani \& Chowdury, 2013). Furthermore, microcredit is considered as an important source of capital for those who do not have access to traditional banking. The effectiveness of microcredit is heavily debated indeed. However, these issues have been extended to the possible consequences with some claiming that this will generate positive results from programmes of women empowerment, while others suggested that it will leave women worse off than before (Kabeer, 2001). The banks are not willing to provide large amounts of funding to women entrepreneurs as they do not have enough confidence in the capacity of a businesswoman. In the case of businesswomen who get capital funding from financial institutions, they might have a very short period of time to pay off the interest. Thus, it is quite tough for women to pay the interest within this short time as it takes a minimum of one year to establish a business for any person. Besides, banks most probably will be willing to provide monetary funding to those who have at least two years running an established business. As a result, there are less opportunities to take loans from the bank at the very initial stage of the business. Besides, banks sometimes receive bribes to give loans to female entrepreneurs, according to respondents in the study done by Obilo (2014). Therefore, women in SMEs in Bangladesh are facing serious problems in accumulating funds for their business (Obilo, 2014). Previous literature highlighted that women entrepreneurs do not have adequate skills in using microfinance facilities (Aliyu, Ahmad, \& Nordin, 2019). Based on the above studies, the following hypothesis was developed:

Hypothesis 4: There is a significant effect of limited access to financial resources to reduce obstacles on women's entrepreneurship growth. 


\subsection{Research Methodology}

\subsection{Sampling Design}

The target population for this study were women entrepreneurs. Based on Tiwari (2017), women entrepreneur refers to women who take the responsibility in managing and organising resources of the business, and accepting all risks with the expectations of gaining profit. There is no specific number of women entrepreneurs in Malaysia. However, the Centre for Entrepreneur Development and Research (CEDAR) stated that $20 \%$ of the estimated totals of more than 650,000 entrepreneurs are women, which is approximately a total of approximately 130,000 women entrepreneurs. Considering that there is no available and definite list of women entrepreneurs in Malaysia, this study has applied a non-probability sampling approach which was convenience sampling. Convenience sampling was selected as it was easy to reach out to respondents with minimum rules. Inconvenience sampling does not have any inclusion of criteria before the selection of subjects. Thus, in this study, every woman entrepreneur that were conveniently sought out by the researcher were the respondents. Previous research suggested that the minimum sample size can be computed either as 10 times the largest formative indicator used to measure one construct, or 10 times the largest number of structural paths directed at a particular latent construct (Hair, Ringle, \& Sarstedt, 2011). In line with this recommendation, the minimum sample size for this study was established at 60 respondents.

\subsection{Research Instrument}

A quantitative research method was adopted in this study whereby a questionnaire was selected as the medium to collect data. Questions for training and education, legal constraint, family-related interface, and limited access to financial resources were adopted from Taqi (2016). Changes were made to suit Malaysian regulation and culture, especially on constructs with regards to legal constraints. In addition, questions on entrepreneur growth were adopted from Kazumi and Kawai (2017), and Baum and Locke (2004). Questionnaires were sent to respondents through an online application and 109 respondents' responses were usable. This meant that the minimum sample size had been achieved. The questionnaire was divided into two sections; one related to the demographic profile of the respondent and the other related to questions for measuring the variables under study using a five-point Likert scale. The five-point Likert scale was used to determine the respondents' agreement on a particular statement. In order to achieve the first objective, critical failure factor analysis was adopted to reflect the obstacles faced by women entrepreneurs. All the items to measure the obstacles were ranked using the relative importance index. The measurement of relative importance index is calculated using the following formula (Somiah, Osei-Poku, \& Aidoo, 2015): 
where:

$\mathrm{w} \quad=$ weight given to each factor ranging from 1 to 5

A $\quad=$ the highest weight

$\mathrm{N} \quad=$ number of respondents

Next, the second objective was achieved using Smart PLS 3 software. Partial Least Square Structural Equation Model (PLS-SEM) was used in analysing the data.

\subsection{Research Findings}

\subsection{Respondent Profiles}

A total of 109 women entrepreneurs were involved in this study. As the objective of this study was not to differentiate the obstacles between the women entrepreneurs' marital status, marital status was considered as not being part of the respondent profile. The majority of 49 respondents were aged within the range of 36 to $45 ; 30$ of them were within the range of 26 to $35 ; 18$ were aged within the range of 46 to 55; seven were aged 55 and above, and lastly five respondents were aged within the range of 18 to 25 . In terms of education, 50 respondents obtained secondary education, 32 were diploma holders, and 21 degree holders, while 6 were postgraduates. Meanwhile, 46 respondents were involved in a variety of businesses; 32 respondents were involved in food and catering; 22 respondents were involved in fashion and beauty, and nine respondents were involved in training and education.

\subsection{Descriptive Analysis}

Table 1

Rank for Training and Education

\begin{tabular}{lccc}
\hline & Mean & Relative Importance Index & Rank \\
\hline Lack of access to high-quality training & 3.688 & 0.738 & 1 \\
Lack of business experience & 3.651 & 0.730 & 2 \\
Lack of connection with experts & 3.422 & 0.684 & 3 \\
Lack of nearby training & 3.202 & 0.640 & 4 \\
Lack of education & 3.064 & 0.613 & 5 \\
\hline
\end{tabular}

The critical failure factor analysis was performed to identify the ranking of obstacles faced by women entrepreneurs. Table 1 presents the rank of critical failure factors for training and education using mean and relative importance index. It is shown that lack 
of access to high-quality training was ranked as the most critical failure factor, while lack of education was ranked as the lowest critical failure factor.

Table 2 presents the ranking of critical failure factors for legal constraints using mean and relative importance index. The highest constraint was on legal derived from obtaining permits and licenses. Thus, this indicated that in certain circumstances, women do face difficulties in attaining permits and licenses.

Table 2

Rank for Legal Constraint

\begin{tabular}{lccc}
\hline & Mean & Relative Importance Index & Rank \\
\hline Legal constraint (permit, license) & 3.661 & 0.732 & 1 \\
Lack of government support & 3.541 & 0.708 & 2 \\
Lack of coordination between various & 3.523 & 0.705 & 3 \\
government departments & & & \\
Lack of law protecting the investment & 3.468 & 0.693 & 4 \\
Business accounting regulation & 3.413 & 0.683 & 5 \\
Tax regulation & 3.404 & 0.681 & 6 \\
\hline
\end{tabular}

Table 3 presents the ranking of critical failure factors for financial resources using mean and relative importance index. The results depicted that poor access to capital as the most critical failure factor in terms of financial resources.

Table 3

Rank for Financial Resources

\begin{tabular}{lccc}
\hline & Mean & $\begin{array}{c}\text { Relative } \\
\text { Importance Index }\end{array}$ & Rank \\
\hline Poor access to capital & 3.633 & 0.727 & 1 \\
Lack of financial resources from banks & 3.578 & 0.716 & 2 \\
Restricted access to certain financial resources & 3.550 & 0.710 & 3 \\
Lack of fund for fixed assets & 3.505 & 0.701 & 4 \\
Inadequate assistance from financial agencies & 3.505 & 0.701 & 4 \\
\hline
\end{tabular}

Table 4 presents the ranking of critical failure factors for the family-related interface using mean and relative importance index. Having young children was found to be the highest obstacles in the ranking of family-related interface, while balancing between family and business was the lowest ranked factor. 
Table 4

Rank for Family-Related Interface

\begin{tabular}{lccc}
\hline & Mean & Relative Importance Index & Rank \\
\hline Having young children & 3.642 & 0.728 & 1 \\
Responsible for all aspects of family & 3.541 & 0.708 & 2 \\
Lacking moral support from family & 3.468 & 0.693 & 3 \\
Stereotype of gender role & 3.422 & 0.684 & 4 \\
Lack of ability to balance between & 3.404 & 0.681 & 5 \\
family and business & & & \\
\hline
\end{tabular}

Subsequently, the result from PLS-SEM on measurement model showed that indicator loading in Table 5 was above the recommended value of 0.70 . In this study, the few items which did not meet the criteria were deleted. The second step was assessing the internal consistency reliability by using composite reliability and Cronbach Alpha. The results of composite reliability reported in Table 5 indicated that the values were within the suggested value of "satisfactory to good" (Hair, Risher, Sarstedt, \& Ringle, 2019). Besides, the outcomes of Cronbach Alpha presented in Table 5 met the rule of thumb as the values had exceeded 0.70 . The third step was examining the convergent validity by conducting the average variance extracted (AVE). Table 5 reported that the AVE achieved the acceptable values of above 0.50 .

This study used the reflective model, following the measurement model by Park, Lee, and Chae (2017). Table 5 presents the measurement model assessment.

Table 5

Measurement Model Assessment

\begin{tabular}{|c|c|c|c|c|c|}
\hline Items & Loading & $\begin{array}{l}\text { Composite } \\
\text { Reliability }\end{array}$ & $\begin{array}{c}\text { Cronbach } \\
\text { Alpha }\end{array}$ & Rho A & $\begin{array}{l}\text { Average Variance } \\
\text { Extracted (AVE) }\end{array}$ \\
\hline $\mathrm{T} 1$ & 0.878 & \multirow{3}{*}{0.893} & \multirow{3}{*}{0.821} & \multirow{3}{*}{0.830} & \multirow{3}{*}{0.662} \\
\hline $\mathrm{T} 2$ & 0.875 & & & & \\
\hline $\mathrm{T} 3$ & 0.82 & & & & \\
\hline L1 & 0.841 & \multirow{4}{*}{0.908} & \multirow{4}{*}{0.865} & \multirow{4}{*}{0.872} & \multirow{4}{*}{0.736} \\
\hline L2 & 0.83 & & & & \\
\hline L5 & 0.85 & & & & \\
\hline L6 & 0.851 & & & & \\
\hline
\end{tabular}




\begin{tabular}{cccccc}
\hline Items & Loading & $\begin{array}{c}\text { Composite } \\
\text { Reliability }\end{array}$ & $\begin{array}{c}\text { Cronbach } \\
\text { Alpha }\end{array}$ & Rho A & $\begin{array}{c}\text { Average Variance } \\
\text { Extracted (AVE) }\end{array}$ \\
\hline F1 & 0.891 & 0.910 & 0.853 & 0.862 & 0.772 \\
F3 & 0.856 & & & & \\
F5 & 0.888 & & & & \\
\hline I1 & 0.853 & & 0.860 & 0.867 & \\
I3 & 0.819 & 0.904 & & \\
I4 & 0.846 & & & \\
I5 & 0.835 & & & & \\
\hline G1 & 0.919 & & 0.893 & 0.895 & \\
G4 & 0.912 & 0.934 & & \\
G5 & 0.893 & & & & \\
\hline
\end{tabular}

From Table 5, $\mathrm{T}=$ training and education, $\mathrm{L}=$ legal constraints, $\mathrm{F}=$ financial resources, $\mathrm{I}=$ family-related interface, and $\mathrm{G}=$ entrepreneur growth.

The final step in the measurement model was to ensure that the Heterotrait-Monotrait Ratio (HTMT) values were less than 0.85 to establish discriminant validity (Hair et al., 2019). The findings revealed that all HTMT values were less than 0.85 . The highest HTMT value was between financial resources and legal constraint, which was 0.786 . These findings are shown in Table 6.

Table 6

Heterotrait-Monotrait Ration (HTMT) Results

\begin{tabular}{ccccc}
\hline & T & L & F & I \\
\hline L & 0.357 & & & \\
F & 0.318 & 0.786 & & \\
I & 0.325 & 0.704 & 0.764 & \\
G & 0.485 & 0.615 & 0.712 & 0.665 \\
\hline
\end{tabular}

From Table $6, \mathrm{~T}=$ training and education, $\mathrm{L}=$ legal constraints, $\mathrm{F}=$ financial resources, $\mathrm{I}=$ family-related interface, and $\mathrm{G}=$ entrepreneur growth.

\subsection{Structural Model}

Confirming that the measurement model had fulfilled all criteria, this study proceeded to examine the structural model. This step was to assess the collinearity among constructs by using the Variance Inflation Factor (VIF) (Hair et al., 2019). The findings showed that VIF was less than 10, which is in accordance with the recommended value of VIF. Thus, the significant relationships were assessed using $\mathrm{R}^{2}$ of the endogenous construct. 
The result showed the $\mathrm{R}^{2}$ value to be 0.486 , which reflects that the four independent constructs explained $48.6 \%$ of the changes in obstacles of women entrepreneurs. This value portrays that obstacles faced by women entrepreneurs suggested in this study have a weak effect on women entrepreneurs' growth, following the suggestion by Hair et al. (2019) that $\mathrm{R}^{2}$ value of 0.75 is substantial, 0.5 is moderate, and 0.25 is weak. Furthermore, $\mathrm{Q}^{2}$ was accomplished by applying blindfolding procedures to determine the quality of the PLS path model. The result of $\mathrm{Q}^{2}$ for construct cross-validated redundancy was 0.381 , which concluded that a medium predictive accuracy of the PLS path (Hair et al., 2019).

Further analysis was conducted to evaluate the proposition in this study by applying 10,000 resampling bootstrapping procedure. The results are reported in Table 7, which shows that the $\mathrm{p}$-value for the path was less than 0.05 with a negative value of mean for training and education, family-related interface, and financial position. This supported hypotheses $\mathrm{H} 1, \mathrm{H} 3$, and $\mathrm{H} 4$, where obstacles faced by women entrepreneurs will lower their entrepreneurship growth. Meanwhile, legal constraints were found to be insignificant as obstacles to women's entrepreneurship growth.

\section{Table 7}

Path Model Analysis to Test Hypothesis

\begin{tabular}{lccccc}
\hline \multicolumn{1}{c}{ Path } & Mean & $\begin{array}{c}\text { Standard } \\
\text { deviation }\end{array}$ & $\begin{array}{c}\mathrm{T} \\
\text { statistic }\end{array}$ & P-Value & Hypotheses \\
\hline Training and education --- growth & -0.237 & 0.071 & 3.228 & 0.001 & Support \\
Legal constraints ---- growth & -0.103 & 0.115 & 0.822 & 0.411 & $\begin{array}{c}\text { Do not } \\
\text { support }\end{array}$ \\
Financial resources ---- growth & -0.334 & 0.118 & 2.897 & 0.004 & Support \\
Family-related interface ---- growth & -0.244 & 0.1 & 2.416 & 0.016 & Support \\
\hline
\end{tabular}

\subsection{Conclusion and Discussion}

This study aimed to explore obstacles faced by women entrepreneurs in developing their venture. As the objective of this study was not to differentiate the obstacles between the women entrepreneur marital status, thus, marital status was not included as part of the respondent profile. Among the items listed were training and education, where lack of access to high-quality training was the highest obstacle ranked. The justification for the results were given as the experts will have better knowledge and experience in a particular business. This is to support that training and education are the highest critical factors for inhibiting women entrepreneurs' growth. Therefore, they need expert knowledge and experience to continue becoming a success, as experts 
can impart knowledge on know-how to deal with customers, competitive markets, availability of resources, and approach suppliers. In this essence, training offers the ability to recognise commercial opportunities, self-esteem, knowledge, and skills (Grecu \& Denes, 2017). Women entrepreneurs may need guidance from these experts to face challenges and enhance their businesses. Teoh and Chong (2014) were of the opinion that difficulties resulted from the small business size as most of them work at home. From the perspective of legal constraints, respondents rated that complying with legal requirements such as procedure-related to permits and licenses, were the biggest challenge for women entrepreneurs. It was foreseen that bureaucracy and approval that needed to be obtained took a long time and incurs additional costs. With regard to financial resources, the findings indicated that poor access to capital is the major hurdle for women entrepreneurs. Some of the women entrepreneurs have limited financial savings and have restricted capital for their ventures. The stability to maintain work capital will be an issue if they are unable to generate consistent profit. In terms of family-related interface, the respondents pointed out that having young children as the main difficulty for women entrepreneurs. Young children need high attention and commitment from parents. Thus, this limits women involvement in the business process. The second objective of this study was to examine how these obstacles affect women entrepreneurs' growth. The findings supported the hypothesis that obstacles lowered the women entrepreneurs' growth. Overall, the results revealed that training and education, limited access to financial resources, and family-related interface would adversely affect women entrepreneurs' growth. Specifically, lack of training and education will lead to challenges in setting up and running the business (Chinomona \& Maziriri, 2015). Besides, this outcome implied that access to financing and capital is essential to produce new products and create new jobs for business expansion. Previous literature highlighted that women entrepreneurs do not have adequate skills in using microfinance facilities (Aliyu et al., 2019). Furthermore, women's responsibilities and commitments restrict their ability to move forward in business. Their obligation toward the family especially their children limits their mobility to generate income (Loveline et al., 2014). The inability to balance their time, energy, and resources between family and business will cause business failure. Surprisingly, legal constraints were found not significant on the obstacles of women entrepreneurs' growth. It shows that regulation is no longer an issue for women to expand their business. Women entrepreneurs may decrease legal impact by applying a proactive strategy and preliminary study (Md Isa et al., 2018).

\subsection{Implications}

Theoretically, this study offers a new women entrepreneurs' model by linking obstacles and growth in a single study. It provides a new insight for future researchers to further research in this field. Practically, this study will benefit many parties involved in 
entrepreneurship including government and non-government agencies in providing support to women entrepreneurs. Specifically, it gives a better understanding of the difficulties faced by women entrepreneurs. In socio-economic terms, this study promotes the international agenda to increase women empowerment as stated in Sustainable Development Goals.

\subsection{Limitation and Recommendations}

The first limitation of this study was the small sample size which only consisted of 109 respondents. Future research is recommended to include a bigger sample size. The second limitation was the small $\mathrm{R}^{2}$ value of 0.486 . Future research is suggested to include more obstacles such as cultural and economic restriction as the additional variables, thus, the $51.4 \%$ can be explained by other factors that were not covered in this study. The third limitation was on the data collection method which was quantitative via distributing questionnaires. Therefore, future research is proposed to collect qualitative data such as from focus group discussions and interviews to get in-depth information and better insight on the intended study.

\section{Acknowledgement}

The authors would like to thank the reviewers for their valuable insights and all the respondents for their contribution to this study.

\section{References}

Akehurst, G., Simarro, E., \& Mas-Tur, A. (2012). Women entrepreneurship in small service firms: Motivations, barriers and performance. The Service Industries Journal, 32(15), 2489-2505.

Aliyu, R. M., Ahmad, T. S. T., \& Nordin, N. (2019). The influence of training on business performance of women entrepreneurs: The mediating role of innovation. Sains Humanika, 11(2-2), 91-97.

Ariff, M., \& Abubakar, S. Y. (2003). Strengthening entrepreneurship in Malaysia. Malaysian Institute of Economic Research, Kuala Lumpur, 1-22.

Baba, G. K. (2013). The challenges of entrepreneurship development in Nigeria and way forward. Journal of Business and Organisational Development, 5(1), 54-64.

Baum, J. R., \& Locke, E. A. (2004). The relationship of entrepreneurial traits, skill, and motivation to subsequent venture growth. Journal of Applied Psychology, 89(4), 587. 
Carter, S. \& Shaw, E. (2006). Women's business ownership: Recent research and policy developments. UK: Small Business Service, 1-96.

Chinomona, E., \& Maziriri, E. T. (2015). Women in action: Challenges facing women entrepreneurs in the Gauteng Province of South Africa. International Business and Economics Research Journal (IBER), 14(6), 835-850.

Global Entrepreneurship Monitor (GEM) Report 2015/2016. Retrieved June 23, 2019, from https://www.gemconsortium.org/file/open?fileId=49480.

Global Entrepreneurship Monitor (GEM) Report 2016/2017. Retrieved June 23, 2019, from https://www.gemconsortium.org/report/gem-20162017-womensentrepreneurship-report.

Gill, R., \& Ganesh, S. (2007). Empowerment, constraint, and the entrepreneurial self: A study of white women entrepreneurs. Journal of Applied Communication Research, 35(3), 268-293.

GMI (2014). Giving credit where it is due: How closing the credit gap for womenowned SMEs can drive global growth. Retrieved August 18, 2014, from http:// www.goldmansachs.com/our-thinking/investing-inwomen/gmi-report-pdf.pdf.

Grecu, V., \& Denes, C. (2017). Benefits of entrepreneurship education and training for engineering students. In MATEC Web of Conferences, 121, 1-7.

Hair, J F., Risher, J. J., Sarstedt, M., \& Ringle, C. M. (2019). When to use and how to report the results of PLS-SEM. European Business Review, 31(1), 2-24.

Hair, J. F., Ringle, C. M., \& Sarstedt, M. (2011). PLS-SEM: Indeed a silver bullet. Journal of Marketing Theory and Practice, 19(2), 139-151.

Haper, C. E. (2004). Conflict management styles, strength of conflict management selfefficiency and moral development levels of school counsellors. Unpublished PhD Thesis, North Carolina State University, USA.

Jahed, M. A., Kulsum, U., \& Akther, S. (2011). Women entrepreneurship in Bangladesh: A study on support services available for its development and growth. Global Management. Review, 5(3), 1-11.

Kabeer, N. (2001). Reflections on the measurement of women's empowerment. In Discussing Women's Empowerment: Theory and Practice. Stockholm: Swedish International Development Cooperation Agency, 17-57.

Kazumi, T. and Kawai, N. (2017), “Institutional support and women's entrepreneurial self-efficacy", Asia Pacific Journal of Innovation and Entrepreneurship, 11(3), 345-365.

Kithae, P. P., Maganjo, R., \& Kavinda, L. (2013). Impact of entrepreneurship training on performance of micro and small enterprises (MSEs) in Kenya: A case study of Embu Municipality. International Journal of Business and Management Review, 1(2), 1-17.

Kuppusamy, J., Ganesan, J., \& Rosada, S. A. (2010). Leadership styles and management techniques: An analysis of Malaysian women entrepreneurs. Communications of the IBIMA 2010, Article ID 817881. 
Loveline, A. A., Uchenna, O. I., \& Karubi, N. P. (2014). Women entrepreneurship in Malaysia: An empirical assessment of the challenges faced by micro and small business owners in Kuching-Sarawak. International Journal of Humanities Social Sciences and Education, 4(1), 48-58.

Maryam, I., Mbasua, A. Y., \& Fatima, U. (2017). Impact of entrepreneurship education and training on women entrepreneurs in Gombe State, Nigeria. Gombe Journal of General Studies, 1(1), 118-189.

Md Isa, F., Jaganathan, M., Ahmdon, S., Afiq, M., \& Mohamad Ibrahim, H. (2018). Malaysian women entrepreneurs: Some emerging issues and challenges of entering global market. International Journal of Academic Research in Business and Social Sciences, 8(12), 1596-1605.

Meherun, N. (2014). Economic empowerment of women through entrepreneurship. A study of Women SME Entrepreneurs in Bangladesh, 1-63.

Minniti, M. (2010). Female entrepreneurship and economic activity. The European Journal of Development Research, 22(3), 294-312.

Norman, M. S. (2013). Essentials of entrepreneurs and small business management (6th ed.) Pearson Education Publication.

Obilo, C. J. (2014). Non-financial factors influencing performance of women owned enterprises in Kenya: A case study of women owned enterprises in Kisauni SubCountry. Research Study of the Management University of Africa, 1-51.

OECD (2019). SMEs and Entrepreneurship Outlook 2019, 1-18.

Olena, H. (2014). Intersectionality 101. Research Study for the Institute for Intersectionality Research and Policy, 1-34.

Park, S., Lee, H., \& Chae, S. W. (2017). Rethinking balanced scorecard (BSC) measures: Formative versus reflective measurement models. International Journal of Productivity and Performance Management. 66(1), 92-110.

Rabbani, G., \& Chowdury, S. (2013). Policies and institutional supports for women entrepreneurship development in Bangladesh: Achievements and challenges. International Journal of Research in Business and Social Science, 2(1), 31-39.

Somiah, M. K., Osei-Poku, G., \& Aidoo, I. (2015). Relative importance analysis of factors influencing unauthorized siting of residential buildings in the SekondiTakoradi Metropolis of Ghana. Journal of Building Construction and Planning Research, 03(03), 117-126. https://doi.org/10.4236/jbcpr.2015.33012.

Taqi, N. (2016). The challenges facing women entrepreneurs: A study on Gulf Cooperation Council (GCC) countries. Doctoral dissertation, Brunel University, London.

Teoh and Chong (2014). Towards strengthening the development of women entrepreneurship in Malaysia. Gender in Management: An International Journal. $29(7), 432-453$.

Tiwari, N. (2017). Women entrepreneurship in India: A literature review. Amity Journal of Entrepreneurship, 2(1), 47-60. 
UNDP (2008). Malaysia nurturing women entrepreneurs. Retrieved June 23, 2019, from ww.my.undp.org /UNDP_Malaysia_NurturingWomenEntrepreneurs.

UNDP Strategic Plan (2018). Executive board of the United Nations Development Programme, the United Nations Population Fund and the United Nations Office for Project Services. 2018-2021. Retrieved June 23, 2019, from https://www. undp.org/content/undp/en/home/sustainable-development-goals.html.

Vossenberg, S. (2013). Women entrepreneurship promotion in developing countries: What explains the gender gap in entrepreneurship and how to close it. Maastricht School of Management Working Paper Series, 8(1), 1-27.

Xavier, S. R., Ahmad, S. Z., Nor, L. M., \& Yusof, M. (2012). Women entrepreneurs: Making a change from employment to small and medium business ownership. Procedia Economics and Finance, 4(1), 321-334. 